\title{
Mucosal Melanoma of the Head and Neck pNX TNM Finding v7
}

National Cancer Institute

\section{Source}

National Cancer Institute. Mucosal Melanoma of the Head and NeckpNX TNM Finding v7. NCl Thesaurus. Code C89136.

Mucosal melanoma of the head and neck in which the regional lymph nodes cannot be assessed. (from AJCC 7th Ed.) 